\title{
КРИМИНАЛИСТИКА КАК ИНИЦИАТОР ОБНОВЛЕНИЯ ПАРАДИГМ ЮРИДИЧЕСКИХ НАУК И УЧЕБНЫХ ДИСЦИПЛИН С УЧЕТОМ ПРИНЦИПА СОСТЯЗАТЕЛЬНОСТИ (ПРОДОЛЖЕНИЕ)
}

\section{Гармаев Ю.П.}

Аннотация: Автор статьи доказывает, что криминалистика как прикладная наука может выступить инициатором изменения или уточнения парадигмы всех юридических наук и учебных дисциплин. Действующая парадигма презюмирует, что в уголовном судопроизводстве господствует так называемая "объективная» правовая позиция и потому подавляющее большинство научных, учебных и прочих публикаций содержат рекомендации по типу: «Лицо совериило то-то, его действия по закону очениваются так-то, а не иначе, что можно доказать с помощью таких-то тактических приемов, технических средств и в таком-то порядке...». Но какое бы решение не принял практический работник, он сделает это не просто как некий абстрактный субъект применения права, а в точности выполняя отведенную ему роль, в основе которой всегда лежит строго определенный корпоративный и/ или состязательный интерес. Методология: диалектика, абстрагирование, анализ, синтез, дедукиия, сравнительно-правовой формально-юридический метод, метод межотраслевых юридических исследований. Обновленная парадигма ориентирована на принцип состязательности уголовного процесса в России и странах Европейского союза, а потому обращяает внимание на широкую распространенность в практике, в мыслительной деятельности криминалистов еще трех, основанньх на законе, правовых позиций: обвинительной и защцттительной позиций, а также позиции судьи. Например, позиция следователя (позиция обвинения) и особенности его мышления: «Есть ли у меня законные основания с учетом фактов, которые я считаю установленными (подлежащими установлению), сделать вывод о квалификации преступлений и их доказывании «по максимально строгому варианту»? Какие места в моей позиции особо уязвимы? Изменится ли позиция суда, если 
атака стороны защиты против моей позиции будет удачной?». При этом речь идет о криминалистическом мышлении в рамках законной правовой позиции, а не о противоправном «обвинительном уклоне». Предлагается пересмотреть традиичонные подходы в научной криминалистической деятельности и дидактике, в том числе, в методологии и методике подготовки учебных и практических пособий. Предлагаемое обновление парадигмы позволит криминалистике обеспечить себе особый междисичилинарный статус в ряду юридических наук и учебных дисичиплин, повысить ее прикладное значение и привлекательность ее «продукиии» для обучающихся и правоприменителей.

Ключевые слова: Криминалистика, Инициатор, парадигма, состязательность, преступление, расследование, предотвращение, судопроизводство, экспертиза, обвинение.

Полагаем, что учет различных позиций и интересов сторон очень важен не только в правоприменительной деятельности, но и в научных исследованиях, и что особенно важно - в учебном процессе, при подготовке учебных и учебно-методических работ, в том числе или даже, прежде всего, - по криминалистике.

\section{3. Правоприменительная практика}

Приведем пример, относящийся к расследованию типичного несложного уголовного дела о коррупционном преступлении. Гражданин с целью получения фиктивного листка нетрудоспособности (в России этот документ - основание для невыхода на работу и начисления пособия по временной нетрудоспособности) передает врачу денежное вознаграждение. Дадим правовую оценку только действиям взяткополучателя.

объективная позиция. Фабула слишком краткая, но наличие состава преступления - получения взятки за совершение заведомо незаконных действий - часть 3 статьи 290 Уголовного кодекса Российской Федерации[1] (далее - УК РФ) - не вызывает серьезных сомнений, что подтверждается широкой распро- страненностью в России уголовных дел подобной категории, где преступления квалифицировались аналогично. Для краткости назовем этот состав основным.

Позиция стороны обвинения. При наличии законных оснований и при инициативном, наступательном подходе в расследовании[2], лицо может и должно быть привлечено к уголовной ответственности «по максимуму», т.е. за совершение трех преступлений:

- получение взятки за незаконные действия (часть 3 статьи 291 УК РФ);

- служебный подлог (статья 292 УК РФ)[3];

- соучастие, в форме пособничества, в мошенничестве, то есть в хищении путем обмана той суммы заработной платы за период мнимой болезни, которую взяткодатель незаконно присвоил благодаря фиктивному листку нетрудоспособности (часть 5 статьи 33 и часть 1 статьи 159 УК РФ).

Не вызывает особых сомнений только наличие основного состава (получения взятки за незаконные действия). Поскольку сторона обвинения, обратим особое внимание - при наличии законных оснований, заинтересована в «отличном результате», то есть в том, чтобы вменить 
«как можно больше и строже»[4], остальные два (дополнительные) нужно доказать и обосновать в части квалификации, а так же выдвинуть и проверить версии, связанные с систематической, многоэпизодной преступной деятельностью данного врача и его коллег. Для этого в ходе расследования следователям с особым вниманием следует отнестись к доказыванию содержания умысла лица и других обязательных признаков дополнительных составов преступлений. В ходе расследования будут проводиться следственные действия, оперативно-розыскные мероприятия и тактические операции, направленные на проверку следующих обстоятельств: осознавал ли взяткополучатель, что при его содействии взяткодатель похитил деньги организации-работодателя; имел ли умысел и корыстный мотив в отношении служебного подлога, и т.д.

Однако решающими факторами в достижении «отличного результата» будут:

- умение следователя расширить объем обвинения новыми эпизодами преступной деятельности;

- способность грамотно описать текст обвинения в постановлении о привлечении в качестве обвиняемого (статья 171 УПК РФ);

- согласование текста обвинения с руководителем следственного органа, надзирающим прокурором и будущим государственным обвинителем; - наличие/ отсутствие в местной судебной практике вступивших в законную силу обвинительных приговоров с подобной квалификацией при подобных обстоятельствах.

При этом представители стороны обвинения должны постоянно мысленно отстраняться от своей позиции и пытаться произвести криминалистическое моделирование адвокатской, которая может быть примерно следующей.

Адвокатская позиция. Предположим, подзащитный признает получение взятки. Даже если фактические основания обвинения уже подтверждены доказательствами, а за это защитнику еще можно побороться, то дополнительных составов в действиях подзащитного нет, так как:

- взяткодатель хотел лишь получить дополнительный отдых и не имел цели хищения, умыслом подзащитного оно не охватывалось;

- получение взятки за незаконные действия охватывает служебный подлог (имеет место правило конкуренции составов - часть 3 статьи 17 УК РФ).

Не исключено, что сторона защиты вообще будет отрицать получение взятки, говоря о провокации преступления, либо иных нарушениях закона при проведении, документировании, представлении результатов оперативнорозыскной деятельности; попытается опровергнуть наличие умысла на незаконность действий, за которые получена взятка: «я думал, что выдаю листок на законном основании. Потому, что пациент жаловался на боли...».

Следует особо оговорить в этой связи следующий момент. В основе самой идеи квалификации как сопоставления признаков совершенного деяния и нормы уголовного закона лежит презумпция того, что в каждой ситуации существует лишь одна единственная верная квалификация[5]. В противном случае реализация принципа законности и поддержание единообразия судебной практики были бы просто невозможными. Предлагаемый подход множественности квалификаций (множества вариантов 
получения, проверки и оценки доказательств) к одному казусу опирается (1) на возможность разной интерпретации фактов (что чаще всего влияет на форму и объем вины), (2) на различие в совокупности фактов, подлежащих квалификации (за счет разброса между вариантами предмета доказывания и отсечения недоказанных надлежащим образом фактов) и (3) неискоренимыми разночтениями в понимании самого уголовного, уголовно-процессуального, иного закона, нескончаемо обсуждаемыми как в доктрине и учебной литературе, так и в следственно-судебной практике. Заметим, что все три изложенных пункта, или как минимум, два первых, имеют криминалистическое содержание, а потому формирование предлагаемой обновленной парадигмы вряд ли возможно иначе, как со стороны криминалистики.

В приведенном примере, если предположим:

- сторона обвинения не сможет выявить и доказать дополнительных эпизодов преступлений, признает основанным на законе ходатайство адвокатазащитника о квалификации действий обвиняемого только по одному составу преступления (часть 3 статьи 290 УК РФ), а этот вариант квалификации, повторим, широко распространен в судебно-следственной практике;

- сторона защиты осознает, что обвинение по части 3 статьи 290 УК РФ вряд ли удастся успешно оспорить не только на следствии, но и в суде, и будет удовлетворена тем, что обвиняемому не вменено еще два состава преступления, не говоря уже о новых эпизодах,

то стороны обвинения и защиты находятся в следственной ситуации, в которой их правовые позиции и законные интересы могут совпасть в той части, что при применении норм гл. 40 УПК РФ обе, вероятнее всего, получат «хороший результат».

\section{4. Правовые позиции в учебном процессе}

На занятии по криминалистике должно моделироваться поведение сторон с использованием каждой из четырех или, как минимум, трех позиций (например, временно опуская позицию суда).

Академический подход - парадигма юридической науки и юридического образования чаще всего ограничивается проблемами однозначной интерпретации закона и правил квалификации. Но и она, применяемая в рамках семинарских занятий по криминалистике и другим предметам антикриминального цикла, позволяет студентам также «играть» с толкованием фактов и определением предмета доказывания.

Суть же нашего предложения сводится не к низвержению и игнорированию, а к необходимости модернизации этой парадигмы (назовем ее, к примеру: «парадигмой объективной позиции») с позиций состязательности и последних достижений криминалистики. Суть модернизации - в научно-дидактическом обеспечении мысленного моделирования сначала той самой объективной позиции, затем позиции каждой из сторон, плюс позиции суда.

На уровне учебных пособий и лекций названная модернизация может быть обеспечена изложенными в настоящей статье положениями с примерами из практики по выбору конкретного преподавателя. На уровне практических занятий 
навыки моделирования различных позиций должны закрепляться в дискуссии в рамках состязательного процесса (его имитации) с использованием образцов и примеров процессуальных документов.

Можно использовать, например, следующую форму - ключевые тезисы позиций (можно излагать в учебно-методическом пособии как шаблон мыслительной деятельности):

1) объективная позиция, присущая, например, ученому: «Считаю ли я сделанный мной вывод о квалификации преступления, доказывании на основании известных фактов правильным и соответствующим смыслу закона?»

2) позиция суда: «Считаю ли я, что сделанный мною вывод о квалификации преступления, доказывании подтвержден допустимыми доказательствами, не противоречит практике высших судов и не имеет фактических ошибок? Есть ли иные варианты квалификации и оценки доказательств, и будут ли они обоснованными? Какова вероятность того, что апелляционная инстанция использует один из этих вариантов, отменив мой приговор?»

3) позиция обвинителя: «Есть ли у меня законные основания с учетом фактов, которые я считаю установленными (подлежащими установлению), сделать вывод о квалификации преступлений и их доказывании «по максимуму»? Какие места в моей позиции особо уязвимы? Изменится ли позиция суда, если атака стороны защиты против моей позиции будет удачной?»

4) позиция защиты: «Есть ли законные основания опровергнуть квалификацию обвинения и сделать вывод о невиновности (меньшей степени вины) подза- щитного? Подтверждена ли моя позиция надлежаще установленными фактами и что будет, если суд не согласится с моей оценкой существенности нарушений при собирании доказательств? Можно ли установленные в суде факты интерпретировать иначе, дополнив картину, например, новыми обстоятельствами?».

\section{5. Выводы}

Обновленная таким образом парадигма образовательной деятельности назовем ее, например, «парадигма четырех позиций», имеет криминалистическую природу, позволит учить и учиться постоянно «играть на опережение», внутренне прочувствовать важность процессуальной формы (и ограничения, ею накладываемые), прийти к осознанию того, что за редким исключением каждая криминалистическая ситуация имеет несколько решений, и каждое из них может соответствовать закону.

Как бы субъективно трудно и непривычно это не казалось некоторым коллегам, но все же считаем, что как ученому и педагогу, так и практикующему юристу и обучаемому, будь то реальное дело или учеба, следует разделять свою мыслительную деятельность на четыре или, как минимум, на три позиции: объективную, обвинительную и адвокатскую, а при необходимости уметь отстаивать каждую из них, прогнозируя, как результат, позицию суда.

Особенно это важно для учебного процесса в вузах и учреждениях по повышению квалификации. Например, на семинарах по уголовному праву, уголовному процессу, криминалистике, в особенности - по криминалистической тактике, кри- 
миналистической методике расследования. Отвечая на вопрос о квалификации и доказывании, тактике расследования и профессиональной защиты по делам о тех или иных преступлениях, обучаемому можно предложить высказать три мнения:

- прежде всего, об объективной позиции, подтвердив ее составленным в порядке домашнего задания постановлением о привлечении в качестве обвиняемого;

- в случае проведения занятия в режиме деловой игры, в зависимости от того, в какой подгруппе он состоит («следователи» или «адвокаты»), изложить обвинительную или адвокатскую позицию. Ее, в свою очередь, необходимо подтвердить, в первом случае, например, постановлением о возбуждении перед судом ходатайства об избрании меры пресечения - содержании под стражей, постановлением об отстранении обвиняемого от должности, а также планом расследования, планами допросов и т.п.; во втором случае, например, жалобой на действия следователя, поданной в порядке статьи 125 УПК РФ, ходатайством о прекращении уголовного дела, планом защитительной деятельности, и т.п.

Кстати, обратим внимание, что в России ни одна из наук антикриминального цикла до сих пор не взяла на себя ответственность за обучение вопросам методики составления процессуальных и иных документов по различным категориям дел, в типичных ситуациях и т.п. И соглашений о совместной междисциплинарной деятельности в этом крайне важном дидактическом направлении что было бы особенно разумно - также не наблюдается. Полагали бы, что именно криминалистика как наука и учебная дис- циплина, научное криминалистическое сообщество, преподаватели вузов могли бы взяться за разработку соответствующих научных положений, прикладных рекомендаций, образцов документов, а также соответствующего программного обеспечения образовательного процесса. А поскольку эта задача междисциплинарная, то криминалисты должны стать инициаторами объединения усилий.

Таким образом, есть все основания полагать, что внедрение в науки и учебные дисциплины антикриминального цикла «парадигмы четырех позиций», развитие междисциплинарного дидактического направления - «методика составления процессуальных и иных документов по различным категориям дел, в типичных ситуациях», соответствующее уточнение концептуальных подходов к формированию и представлению теоретических положений, учебных и практических рекомендаций, к обучению будущих и действующих правоприменителей - все это позволит сделать важный шаг к уточнению парадигм, модернизации наук и учебных дисциплин антикриминального цикла (впрочем, как и иных юридических), повышению эффективности всей правоприменительной практики.

Инициатива о внедрении «парадигмы четырех позиций» в совокупности с идеей актуализации методики составления процессуальных документов не могла появиться иначе, как в рамках криминалистических исследований, поскольку она основана на идеологии и лучших достижениях криминалистики, лишний раз демонстрируя инновационный вектор ее развития, прагматичный характер и прикладную направленность ее разработок. 


\section{Библиография:}

1. «Маркин: в России 0,4\% оправдательных приговоров»// Сайт «Русская служба ВВС» [Электронный ресурс]: // Режим доступа:http://www.bbc.com/russian/ russia/2015/01/150120_markin_acquittal_rate_court_russia - Загл. с экрана. (дата обращения 01.05.2015).

2. Уголовный кодекс Российской Федерации от 13 июня 1996 г. N 63-Ф3 (с изменениями от 30 марта 2016 г.) [Электронный ресурс] // Режим доступа: http://www.consultant. ru/document/cons_doc_law_10699/._-Загл. с экрана. (дата обращения 01.05.2016).

3. Гармаев Ю.П. Принцип наступательности в выявлении и расследовании преступлений / Ю.П. Гармаев // Российский следователь. 2016. № 2. С. 6-12.

4. П. 22 Постановления Пленума Верховного суда РФ от 09.07.2013 № 24 «О судебной практике по делам о взяточничестве и об иных коррупционных преступлениях» в той части, что совершение должностным лицом за взятку действий (бездействие), образующий самостоятельный состав преступления, не охватывается объективной стороной преступления, предусмотренного статьей 290 УК РФ.

5. Кудрявцев В.Н. Общая теория квалификации преступлений / В.Н. Кудрявцев. 2-е изд., перераб. и доп. М.: Юристъ, 2007. 302 с.; Дуюнов В.К. Квалификация преступлений: законодательство, теория, судебная практика [Текст]: монография / В.К. Дуюнов, А.Г. Хлебушкин. М.: Риор: ИНФРА-М, 2013. 372 с.

\section{References (transliterated):}

1. «Markin: v Rossii 0,4\% opravdatel'nykh prigovorov» // Sait «Russkaya sluzhba BBC» [Elektronnyi resurs]: // Rezhim dostupa:http://www.bbc.com/russian/russia/2015/01/150120_ markin_acquittal_rate_court_russia - Zagl. s ekrana. (data obrashcheniya 01.05.2015).

2. Ugolovnyi kodeks Rossiiskoi Federatsii ot 13 iyunya 1996 g. N 63-FZ (s izmeneniyami ot 30 marta 2016 g.) [Elektronnyi resurs] // Rezhim dostupa: http://www.consultant. ru/document/cons_doc_law_10699/._Zagl. s ekrana. (data obrashcheniya 01.05.2016).

3. Garmaev Yu.P. Printsip nastupatel'nosti v vyyavlenii i rassledovanii prestuplenii / Yu.P. Garmaev // Rossiiskii sledovatel'. 2016. № 2. S. 6-12.

4. P. 22 Postanovleniya Plenuma Verkhovnogo suda RF ot 09.07.2013 № 24 «O sudebnoi praktike po delam o vzyatochnichestve i ob inykh korruptsionnykh prestupleniyakh» v toi chasti, chto sovershenie dolzhnostnym litsom za vzyatku deistvii (bezdeistvie), obrazuyushchi samostoyatel'nyi sostav prestupleniya, ne okhvatyvaetsya ob"'ektivnoi storonoi prestupleniya, predusmotrennogo stat'ei 290 UK RF.

5. Kudryavtsev V.N. Obshchaya teoriya kvalifikatsii prestuplenii / V.N. Kudryavtsev. 2-e izd., pererab. i dop. M.: Yurist', 2007. 302 s.; Duyunov V.K. Kvalifikatsiya prestuplenii: zakonodatel'stvo, teoriya, sudebnaya praktika [Tekst]: monografiya / V.K. Duyunov, A.G. Khlebushkin. M.: Rior: INFRA-M, 2013. 372 s. 